\title{
The Influence of College Ranking on the Development Strategy of Colleges and Universities
}

\author{
Lan $\mathrm{Wu}^{1}$, a \\ ${ }^{1}$ beihua University, no.3999, hua shan road, jilin city, jilin province, China \\ a648486586@qq.com
}

\begin{abstract}
Keywords: College ranking; Influence; Employment; School Selection; Social resources; Cultural capital
\end{abstract}

\begin{abstract}
As the institutions of higher learning are becoming increasingly international and popular during the development, college ranking has become one of the most popular topics in recent years, which is mainly because that college ranking is social and open, which to a certain extent satisfies the society and public's demands for evaluating colleges and universities. More importantly, it can provide students with valuable referential information in school selection. However, at the same time, the controversy arising from college ranking has never stopped because college ranking will have huge influence on college and universities' economic efficiency, integration of social resources, the public, government decisions, college students' employment rate and enrollment rate, etc. In short, college ranking's positive influence and negative influence coexist in the development of China's education. The society, government, colleges and universities, parents and students should correctly view and interpret college ranking. Meanwhile, relevant institutions and departments should also make the colleges' evaluation system and evaluation subjects more standardized and systematic so as to ensure that college ranking can become the best supervision and evaluation system to improve the teaching quality of colleges and universities.
\end{abstract}

\section{The Ideal Intention of Creating College Ranking}

Any form of ranking must be generated for a certain purpose, and college ranking is of course not an exception. WU Shulian, et. Al. once clearly put forward in "Evaluation of Chinese Colleges and Universities" that "college ranking should provide reference for graduating high school students and graduating college students to apply for colleges and graduate schools". From the perspective of economics, this is a typical "customer-oriented" ranking, in which the evaluation mechanism is established with "customers' demands" as the orientation so as to give the colleges and universities reputation, high-quality applicants, social resources, education funds and various added value, etc. College ranking is often used to measure the degree and quality of education received by students, which in other words means that college ranking has already become one of the important indexes to evaluate colleges and universities' teaching quality. With the continuous development of the economy and the continuous progress of the society, people's horizons and understanding are broader and more profound than before, and their observation and judgment of things are no longer confined to a certain level or angle. Therefore, college ranking will finally influence students' selection of schools, the flow of social resources and education funds, college students' employment rate and the competition among colleges and universities, thus it will definitely greatly promote the development of colleges and universities and social progress. In fact, college ranking has long been popular in Western developed countries. It can be used to observe and evaluate the teaching level and development prospect of colleges and universities in an all-round way and from various perspectives, and it can help colleges and universities examine their own problems and deficiencies and provide them with an exchange platform and opportunities for mutual reference and learning, thus stimulating and encouraging the progress of colleges and universities. For customers, they can get to know many information about colleges and universities from the college ranking list so as to have broader space to choose schools. However, from the current influence of 
college ranking, although the influence of college ranking has been increasing, its role has seriously deviated from the original purpose. Therefore, we must re-face and interpret college ranking, view the development and impact of college ranking in a dialectical manner so as to timely adopt effective measures to eliminate the negative influence of college ranking and create more social benefits.

\section{The Important Influence of College Ranking on the Establishment of College Image and Brand Construction.}

With the constant deepening of China's education reform and the intensified competition for talents, the development of higher education has been receiving more and more attention from the state and the government. In order to create a better living environment and development space, some colleges and universities are facing unprecedentedly huge pressure. They need to fight with not only colleges and universities at the same level for talents, but also universities in the "211 Project" and "985 Project" which they have huge difference with. Thus, it can be imagined that in order to survive and develop, these colleges and universities need to spark a bloody way in the intense competition. The image and brand of a college or university, as an objective existence of the intangible educational resources, can bring excessive economic benefits for colleges and universities. Meanwhile, they are also one of the most intuitive and effective ways for colleges and universities to show their educational strength and compete for educational resources. For some not well-known colleges and universities, to establish a healthy image and clutch the brand construction has already become an inevitable choice for them to optimize the living environment and win the competitive initiative. Therefore, more and more colleges and universities are striving to improve their personal images and strengthen the brand construction to fight foe talent resources and educational resources and put these resources into brand construction. However, it should be clarified that any behavioral activity and form of competition cannot completely get rid of the constraints of the social environment. They will be more or less affected by social factors. And for domestic well-known universities, ordinary colleges and universities are more subject to the influence and harassment of social factors. Among these social factors, college ranking has the biggest, broadest and most profound influence on the establishment and construction of college image and brands, and it is usually regarded by the society and public as the truest internal reflection of college reputation. Therefore, in recent years, each Chinese college and university, particularly ordinary colleges and universities are attaching more importance to the establishment and spreading of their own images in a bid to improve social reputation, create positive and health brand images. Thus, it can be seen that college ranking has unknowingly become one of the most factors affecting colleges and universities to making educational decisions, reform measures and management means. And its position in the development of colleges and universities is constantly ascending. Thus, there is no exaggeration that college ranking can even decide the "survival and death" of a college or university from a certain angle.

At present, because some colleges and universities hope to use college ranking to expand the publicity effect and they even use some improper means to require some newspapers or other news organizations to publicize their favorable ranking, thus at present, there are various versions of college ranking, and even some misleading and groundless ranking can also be found everywhere on the Internet and people's life. In fact, we should correctly view college ranking in a dialectical manner, because its evaluation of colleges and universities' teaching level and teaching quality is relative, so it should not be used as a partial division of colleges and universities' level as well as the overall evaluation of colleges and universities. Indeed, it is undeniable that college ranking can promote the development of colleges and universities, but we should also be alert to the potential crisis caused by college ranking. 


\section{The Important Influence of College Ranking on the Policy and Behavior Organization of Colleges and Universities}

The influence of college ranking on college policies and behavioral organizations mainly comes from the employers, parents and students, thus forming a pressure on colleges in decision-making and behavioral organizations in terms of non-cultural development and education reform. Under this pressure, colleges and universities usually choose to study the various indexes and bases of college ranking so as to find whether they need to make improvement and their own defects, and then they will take effective organizational behaviors or change the policies according to their deficiencies so as to improve their ranking on college ranking and their competitiveness in education. A large number of research data show that college ranking subtly affect colleges and universities' management decisions, education policies, rules and regulation design, educational reform ideas and major setting, etc., which is specifically embodies in the integration and distribution of educational resources, personal transfer and employment, recruitment decisions, setting of majors, temporary decision-making and other aspects.

It can be found from comparing all the college ranking indexes and key points in recent years that because of the different internal characteristics of different colleges and universities and different resources, as well as the different educational systems in colleges and universities, college ranking indicators of the composition of the evaluation system will naturally be different, but in the construction of the index system will certainly be all emphasized and focused. Generally speaking, the ranking of all kinds of colleges and universities is nothing more than the evaluation of university reputation, education costs and institutions and other facilities to focus on university personnel training, social services and scientific research and other aspects of investment and performance, including education costs and hospital School facilities in the indicators of the higher value, which is mainly due to the size of institutions, dormitory decoration, the total amount of books, educational equipment, the proportion of teachers and students and graduate employment rate by the intensity of government investment and university scale impact, And optimize and improve the difficulty coefficient. And some colleges and universities because of the shortage of funds for education, education facilities and the lack of teachers and teachers, blindly expand the scale of enrollment and the establishment of new professional, basic education funds and school conditions cannot meet the follow-up educational needs, will inevitably reduce the teaching of institutions Quality, the newly established professional is also very difficult to run long, long past, the reputation of colleges and universities will inevitably be a serious blow. In addition, the university's scientific research projects, scientific research, research funding and academic award situation will be included in the evaluation mechanism. Therefore, colleges and universities tend to use quantitative analysis of the previous research data and research results to sort out and sum up, and through the institutions of supervision and management departments to obtain the latest college ranking situation, so that the data obtained by the information as complete as possible, complete. The negative impact of this approach is mainly reflected in two aspects: first, too much emphasis and the pursuit of scientific research, imitation and reference phenomenon is more serious, there is no solid scientific research and rigorous academic atmosphere; second, Too much emphasis on scientific research and neglect of the students in the training and improvement, leading to teaching results and scientific research results seriously imbalance, inhibit the healthy development of colleges and universities. It can be seen that the correct choice of college ranking can promote the development and progress of colleges and universities to a certain extent, to enhance the level of teaching and teaching level. On the contrary, if the extreme thinking and attitude towards college students, will bring institutions a lot of negative effects, even with college singers created the original intention of running away. Therefore, we must correctly understand the college ranking based on the university's management policy and organizational behavior to make appropriate adjustments to ensure that the quality of teaching in colleges and universities have been further sublimation. 


\section{Rational Understanding of the Influence of College Ranking on Institutions}

However, it cannot be denied that the influence of colleges and universities is objective and inevitable. Although it can evaluate, test, protect and supervise the quality of teaching in colleges and universities, it can expand the brand effect of colleges and universities imperceptibly, but it cannot be denied that the negative impact of the college ranking is also true, so we must rationally understand it and face it.

For the same college ranking, different colleges and universities often use the same evaluation indexes, and the evaluation indexes cover a wide range and involve complicated contents, which is very beneficial for colleges with a long history and large scale, but it is unfavorable for colleges with a short history and small scale. In other words, it is necessary to make the college ranking indexes more fair and just so as to cub or eliminate some colleges that are still at the development stage. The unification of the system will not only benefit the diversification and diversification of the school, but also hinder the school 's characteristic construction and behavioral activities, so that the higher education has lost the original A variety of value training, multiple quality assurance and diverse educational development of educational philosophy and purpose of running a school. Therefore, the use of the same value judging system to evaluate the irrationality of all colleges and universities, unscientific and incomplete can be imagined, but also will inevitably bring a lot of adverse results, for example, some colleges and universities too much emphasis on ranking, breaking the original design of the good institutions of the development of strategic planning, and instead of ranking indicators to optimize the internal education structure and teaching policy, making the institutions in the development cannot highlight the original characteristics of the school, and then making colleges and universities lose more excellent students.

In fact, researches into college ranking should not only stay at the comprehensive competitiveness, which is merely one of the indexes to evaluate a college's strength, but cannot truly stand for or demonstrate a college's real strength and advantages. Besides, over-emphasis on and pursuit of college ranking is also contrary to the advocated principle of fairness and is not conducive to the progress and development of colleges and universities. In this case, college ranking is also being constantly explored and improved in controversy. For example, in the "Comprehensive Competitiveness of Chinese Universities" prepared by the China Science Evaluation Center of Wuhan University, in addition to the ranking of colleges and universities' comprehensive strength, there are also clear denotation of the major ranking, type ranking and Level-I subject ranking of colleges and universities. This kind of directional objective ranking can help people to more in-depth and comprehensive understanding of the major colleges and universities, a clear university development advantages, disadvantages and to be optimized and improved aspects, making college ranking advantage is fully played out, greatly inhibiting the negative impact of colleges.

All in all, existence is rational and college ranking is no exception. China's college ranking is still at the development and improvement stage. Colleges and universities cannot only require the positive influence or to completely eliminate the negative influence, but should objectively, rationally, dialectically, comprehensively and scientifically understand and interpret the influence and functions of college ranking from multiple perspectives, based on which they would try to use college ranking as much as possible to play the monitoring and supervising role of college ranking according to the actual situation of colleges and universities to make sure that relevant policies at colleges and universities are changed rationally and scientifically. This can effectively promote the strategic development and progress of schools and further improve colleges and universities' teaching features, scientific research results, academic quality and teaching level.

\section{References}

[1] SONG Wei, XIAO Nian. A Study on the Influence of College Ranking on the Development of Colleges and Universities. [J] Beijing Education (Higher Education). 2013.02. 
[2] XIE Yalan. Research on the Index System and Influence of College Ranking [M]. Shanghai Jiaotong University's doctoral thesis. 2010.42.

[3] CHEN Lin, LI Xueping. The Negative Influence of University Ranking on Local Colleges' Brand Construction and the Countermeasures. Journal of Gannan Normal University. 2014.02.

[4] LIU Yang. An Analysis of the Problems and Countermeasures of College Ranking in China [J]. China Electric Power Education. 2011(11).12.

[5] ZHANG Wang. The Influence of College Ranking on Colleges and Universities [J]. Development and Evaluation of Higher Education. 2012.(01).24.

[6] ZHAO Qian. Research on the Phenomenon of College Ranking in China - Causes, Advantages and Disadvantages and Suggestions. [J]. Journal of Shenyang Institute of Engineering (Social Science Edition). 2013.02.

[7] WEN Yixian. Rational Thinking on the Ranking of Domestic Universities [J]. China Electric Power Education. 2011.10.

[8] SHI Juan. Reflections on the College Ranking in China [J]. Research on Higher Education of Science and Engineering.2009.

[9] WANG Zhanjun. The Influence of College Ranking on Organizational Decision - making, Behavior and Culture of Colleges and Universities [J]. Chinese Higher Education Research. 2012.(02):25.

[10] LE Guolin, ZHANG Li. A Sociological Analysis of the Impact of College Ranking on Colleges and Universities - Based on the Bourdieu Field and Capital Theory [J]. Modern Education Science. 2005 (03);127.

[11] GENG Youquan. A Rational Reflection on the Ranking of Chinese Universities [J]. Journal of Educational Science. 2010 (05);58 